\title{
Effect of harvest date and ripening degree on quality and shelf life of Hass avocado in Mexico
}

\author{
Jorge A. OsunA-García ${ }^{1 *}$, Gilles Doyon ${ }^{2}$, Samuel SaLAZAR-García ${ }^{1}$, Ricardo GoenagA ${ }^{3}$, Isidro J.L. GonZÁLeZ-DuRán ${ }^{1}$
}

1 INIFAP-Campo Exp.

Santiago Ixcuintla, A.P. 100, Santiago Ixcuintla, Nayarit 63300, México, osuna.jorgealberto@inifap. gob.mx

${ }^{2}$ Food Res. Dev. Centre, Agric. Agri-Food Canada, 3600 Casavant Blvd. West, St. Hyacinthe, Quebec, Canada J2S 8E3

${ }^{3}$ USDA-ARS, Trop. Agric. Res. Stn., 2200 P.A. Campos Ave., Suite 201, Mayagüez, Puerto Rico 00680-5470, USA

* Correspondence and reprints

Received 25 January 2010 Accepted 04 March 2010

Fruits, 2010, vol. 65, p. 367-375 (C) 2010 Cirad/EDP Sciences All rights reserved DOI: $10.1051 /$ fruits/2010031 www.fruits-journal.org

RESUMEN ESPAÑOL, p. 375

\section{Effect of harvest date and ripening degree on quality and shelf life of Hass avocado in Mexico.}

Abstract - Introduction. Canada is an important avocado importer from Mexico. For most of the harvest season, fruit reach adequate pulp dry matter content, ripen properly and, consequently, quality and shelf life are excellent. However, after January, fruit dry matter content increases and blackened skin occurs. Shipments to Canada containing blackened fruit are rejected because this characteristic is wrongly associated with low pulp firmness and short shelf life. The objective of our research was to determine the effect of harvest time and ripening degree on initial quality and shelf life of Hass avocado. Materials and methods. Fruit were harvested from October 2007 to April 2008, and grouped into five ripening categories according to the degree of blackened skin. Fruit were then refrigerated for $7 \mathrm{~d}$ to simulate shipment to Canada. Thereafter, fruit were stored under simulated market conditions until they reached the edible ripening stage. Dry matter content was calculated only at the beginning of the storage period while quantification of weight loss, fruit with blackened skin, pulp firmness, and pulp color was done at the beginning of the storage period, at the end of the refrigeration period, and every three days during market conditions. Results and discussion. Dry matter content, skin color and pulp hue angle significantly increased with harvest date and ripening degree. Weight loss decreased with harvest date but increased with ripening degree, while firmness was affected by harvest date but was not associated with ripening degree. Conclusion. There is no reason to reject or downgrade blackened fruit, since quality and shelf life are not affected.

Mexico / Persea americana / fruits / ripening / dry matter content / weight losses / color / peel / firmness

\section{Effet de la date de récolte et du degré de maturation sur la qualité et la durée} de vie de l'avocat Hass au Mexique.

Résumé - Introduction. Le Canada est un important importateur d'avocats en provenance du Mexique. Pour la plupart des saisons de récolte, les fruits atteignent une teneur adéquate en matière sèche de la pulpe, mûrissent correctement et, par conséquent, leur qualité et leur durée de vie sont excellentes. Toutefois, après janvier, la teneur en matière sèche des fruits augmente et un noircissement de la peau se produit. Les expéditions vers le Canada contenant des fruits noircis sont rejetées parce que cette caractéristique est faussement associée à une faible fermeté de la pulpe et une courte durée de conservation. L'objectif de notre recherche a été de déterminer l'effet de la date de récolte et du degré de maturation sur la qualité initiale et la durée de vie de l'avocat Hass. Matériel et méthodes. Des fruits ont été récoltés d'octobre 2007 à avril 2008 et regroupés en cinq catégories de maturation en fonction du degré de noircissement de la peau. Ces fruits ont été ensuite mis au réfrigérateur pendant 7 jours pour simuler une expédition au Canada. Ensuite, les fruits ont été entreposés dans des conditions simulant leur mise en marché jusqu'à ce qu'ils atteignent le stade comestible. La teneur en matière sèche n'a été calculée qu'en début de la période de stockage tandis que la perte de poids, le noircissement de la peau des fruits, la fermeté de la pulpe et la couleur de la pulpe ont été évalués en début de la période de stockage, à la fin de la période de réfrigération, puis tous les trois jours pendant leur stockage en conditions de marché. Résultats et discussion. La teneur en matière sèche, la couleur de la peau et la coloration de la pulpe ont significativement augmenté avec la date de récolte et le degré de maturation. La perte de poids a diminué avec la date de récolte, mais elle a augmenté avec le degré de maturation tandis que la fermeté du fruit a été affectée par la date de récolte, mais n'a pas été associée au degré de maturation. Conclusion. Il n'y a aucune raison de rejeter ou d'écarter les avocats noircis, parce que ce caractère n'affecte pas leur qualité et leur durée de conservation.

Mexique / Persea americana / fruits / mûrissage / teneur en matière sèche / perte de poids / couleur / pelure / fermeté 


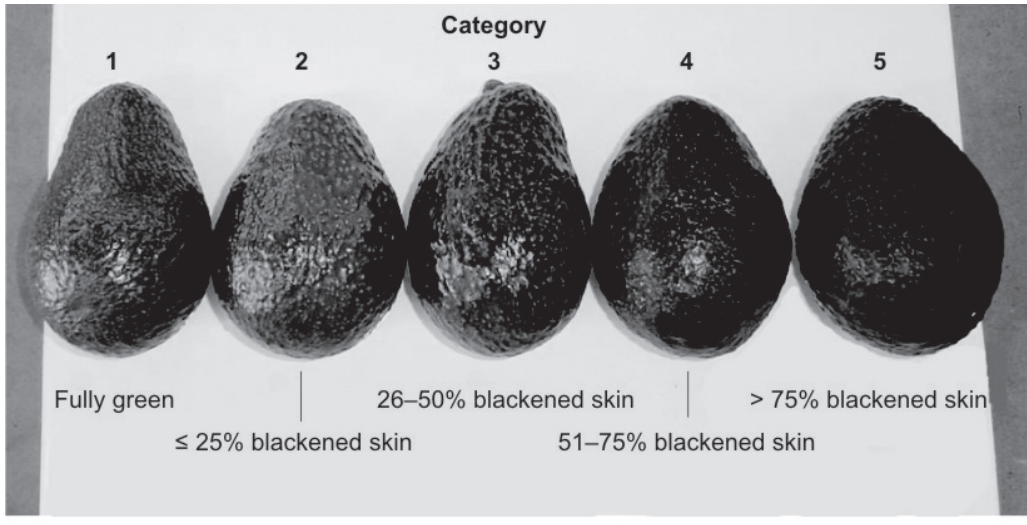

Figure 1.

Categories of Hass avocado fruit according to the degree of blackened skin.

\section{Introduction}

Mexico is the main exporter of Hass avocado in the world. Fruit exports increased from $135,872 \mathrm{t}$ during 2004 to $310,260 \mathrm{t}$ in $2007^{1}$. According to the Mexican Avocado Growers and Packers Association ${ }^{2}$, this increase is the result of improved fruit quality due to better cultural practices used to grow the crop and packing methods which have opened new market niches throughout the USA. About 90\% of total avocado production in Mexico occurs in the state of Michoacan. The main importer countries of Mexican avocado are the USA, Japan, the European Union and Canada.

The different bloom flushes and their overlapping between different altitude zones in Michoacan make it possible to harvest Hass avocados all year round. However, the most important commercial harvest season for Hass avocado extends from September to late April [1]. Avocado fruit harvested early in the season often do not reach the minimum pulp dry matter content market criteria (i.e., legal maturity of $21.5 \%$ ). Lower fruit dry matter is associated with irregular ripening (immature fruit become watery, rubbery, flavorless, shriveled and blackened), and reduced shelf life [2]. Fruit harvested from mid-October to early January reach adequate dry matter content (>21.5\%) and, consequently, ripen properly and have an excel-

\footnotetext{
${ }^{1}$ http://faostat.fao.org, consulted in March, 2010.

2 http://www.apeamac.com, consulted in March, 2010.
}

lent shelf life. Fruit harvested after midJanuary attain high dry matter content (> 28\%), thus meeting legal maturity standards; however, fruit also develop blackness of the skin during this period. Preliminary results indicated that a higher degree of skin blackening was associated with less pulp firmness at packing time and that further studies with several harvest dates throughout the harvest season were needed to determine how skin blackening might influence Hass avocado shelf life [3].

The color change in Hass avocado from green to purple/black as fruit ripen is an important ripeness indicator for both industry and consumers. This color change results from an initial decrease in chlorophyll content, followed by an increase in the anthocyanin cyanidin 3-O-glucoside [4]. Unlike other fruit crop species, avocado fruit will not mature and ripen while on the tree but several days after being harvested [5]; a desired trait as it allows growers to delay harvesting if market prices are not acceptable [6]. Research has shown that the longer the fruit remain on the tree, the pulp oil and dry matter contents as well as the degree of blackened skin become higher [7, 8]. Latepicked fruit reach maturity faster than those harvested at legal maturity [9]. In Michoacan, about $80 \%$ of the avocado orchards are located at an altitude ranging between (1600 and 2200) $\mathrm{m}$ above sea level and trees have up to four flowering flushes, making Hass avocado available all year round [10]. Recently, Hass avocado shipments to Canada containing fruit with blackened skin have been rejected because this characteristic is wrongly associated with low pulp firmness and short shelf life by consumers. This situation prompted the authors to conduct the research described herein in order to assess the effect of harvest time and ripening degree on quality traits and shelf life of Hass avocado.

\section{Materials and methods}

Our study was carried out in Michoacan, Mexico. Fruit were collected in October and December 2007 and from January to April 2008, at the 'Moribito' and 'Providencia' 
Table I.

Effect of harvest date and ripening degree on dry matter content (\% of fresh weight) of Hass avocado fruit (Mexico).

\begin{tabular}{lccccccc} 
Ripening & \multicolumn{4}{c}{ Harvest date } & \multicolumn{2}{c}{ Average } \\
degree & October & December & January & February & March & April \\
& $20.5 \mathrm{a}$ & $29.8 \mathrm{a}$ & $29.5 \mathrm{c}$ & $31.6 \mathrm{~b}$ & $33.8 \mathrm{c}$ & $31.7 \mathrm{c}$ & $29.5 \mathrm{~d}$ \\
1: fully green & - & $30.6 \mathrm{a}$ & $30.2 \mathrm{c}$ & $33.1 \mathrm{ab}$ & $35.0 \mathrm{bc}$ & $32.0 \mathrm{c}$ & $32.9 \mathrm{c}$ \\
2: $\leq 25 \%$ blackened skin & - & - & $33.7 \mathrm{ab}$ & $33.0 \mathrm{ab}$ & $36.3 \mathrm{ab}$ & $33.6 \mathrm{bc}$ & $34.1 \mathrm{~b}$ \\
3: $26-50 \%$ blackened skin & - & - & $31.7 \mathrm{bc}$ & $34.5 \mathrm{a}$ & $35.4 \mathrm{bc}$ & $35.0 \mathrm{ab}$ & $34.1 \mathrm{~b}$ \\
4: $51-75 \%$ blackened skin & - & - & $34.3 \mathrm{a}$ & $33.2 \mathrm{ab}$ & $38.2 \mathrm{a}$ & $35.9 \mathrm{a}$ & $34.7 \mathrm{a}$ \\
5: $>75 \%$ blackened skin & $20.5 \mathrm{D}$ & $30.2 \mathrm{C}$ & $31.9 \mathrm{C}$ & $33.1 \mathrm{~B}$ & $35.7 \mathrm{~A}$ & $33.7 \mathrm{AB}$ & -
\end{tabular}

Values with the same letters within columns are statistically equal (Waller-Duncan $P \leq 0.05$ ).

Values with the same capital letter within the last row are statistically equal (Waller-Duncan $P \leq 0.05$ ).

packinghouses. Fruit were grouped into five ripening categories according to the degree of blackened skin: 1 = fully green, $2 \leq 25 \%$ blackened skin, $3=26-50 \%$ blackened skin, $4=51-75 \%$ blackened skin and $5>75 \%$ blackened skin (figure 1).

Fruit were refrigerated inside a cold storage room $\left[(6 \pm 1){ }^{\circ} \mathrm{C} ;(90 \pm 5) \% \mathrm{RH}\right]$ for $7 \mathrm{~d}$ to simulate terrestrial shipment to Canada. After this period, fruit were stored under simulated market conditions $\left[(22 \pm 2){ }^{\circ} \mathrm{C}\right.$; $(75 \pm 10) \% \mathrm{RH}]$ until they reached the edible ripening stage [skin fully black and pulp firmness between ( 5 and 15) N].

Pulp dry matter content was calculated at the beginning of the simulation of terrestrial shipment while weight loss, fruit with blackened skin, pulp firmness and pulp color were determined at the beginning of the simulation of terrestrial shipment, at the end of the refrigeration period, and every three days during market conditions.

Dry matter was determined by cutting $10 \mathrm{~g}$ of pulp longitudinally into thin slices using a potato peeler. The slices were taken from the middle of the fleshy portion to ensure uniform oil content [11]. Slices were placed in glass Petri dishes and dried in a microwave oven for 6-10 min until constant weight [12]. The percent dry matter content was calculated as [(dry weight / fresh weight $\times 100$ ]. Weight loss was determined by weighing 10 fruits using an analytical digital balance (Acculab VI-4800) with an accuracy of $0.1 \mathrm{~g}$. The difference in weight with respect to initial weight was expressed as weight loss.
Blackened fruit were determined in the same lot of fruit used to obtain weight loss. A fruit was considered black when its skin changed color from green to fully black. Firmness was measured using a DFE-050 Chatillon penetrometer (Ametek Instruments, Largo, FL, U.S.A.) with a $10-\mathrm{mm}$ diameter head. A portion of the skin of approximately $5 \mathrm{~mm}$ was removed in the equatorial region of each fruit to expose the pulp and the probe was inserted at about $4 \mathrm{~mm}$ depth at a speed of $180 \mathrm{~mm} \cdot \mathrm{min}^{-1}$. Firmness was expressed in Newtons (N). Pulp color was determined using a CR 10 portable color reader (Konica Minolta Sensing Inc., Japan) reporting as hue angle.

For dry matter, weight loss and blackened fruit determination, the sample consisted of 10 fruits for each harvest date and ripening degree category, while, for firmness and pulp color, six fruits were used.

The treatment design was a $(6 \times 5)$ factorial in a completely random design [13] where the factors were harvest date and ripening degree categories. Analysis of variance was conducted using the GLM procedure of SAS [14]. Means separation was performed using the Waller-Duncan procedure at $P \leq 0.05$.

\section{Results and discussion}

\subsection{Pulp dry matter}

Pulp dry matter increased with harvest date and degree of blackened skin (table I). The 


\section{Table II.}

Effect of ripening degree on accumulated weight loss (\%) of Hass avocado fruit by harvest date, in relation with the sampling dates during storage. Harvest : beginning of the simulation of terrestrial shipment inside a cold storage room for $7 \mathrm{~d} ;(7+0) d$ : end of the refrigeration period; $(7+3) d,(7+5) d,(7+7) d,(7+10) d$ : samplings every $3 d$ during storage with market conditions.

\begin{tabular}{|c|c|c|c|c|c|c|}
\hline \multirow[t]{2}{*}{ Ripening degree } & \multicolumn{6}{|c|}{ Sampling date } \\
\hline & Harvest & $(7+0) d$ & $(7+3) d$ & $(7+5) d$ & $(7+7) d$ & $(7+10) d$ \\
\hline \multicolumn{7}{|c|}{ October (average weight loss $7.1 \%$ ) } \\
\hline 1: fully green & 0 & 2.6 & 5.7 & 7.0 & 8.4 & 11.6 \\
\hline \multicolumn{7}{|c|}{ December (average weight loss 6.6\%) } \\
\hline 1: fully green & $0 \mathrm{a}$ & $2.3 \mathrm{a}$ & $5.6 \mathrm{a}$ & $7.8 \mathrm{a}$ & $9.7 \mathrm{a}$ & $11.6 \mathrm{a}$ \\
\hline $2: \leq 25 \%$ blackened skin & $0 \mathrm{a}$ & $2.5 \mathrm{a}$ & $5.9 \mathrm{a}$ & $8.1 \mathrm{a}$ & $10.3 \mathrm{a}$ & $12.3 \mathrm{a}$ \\
\hline \multicolumn{7}{|c|}{ January (average weight loss $4.8 \%$ ) } \\
\hline 1: fully green & $0 \mathrm{a}$ & $1.7 \mathrm{bc}$ & $4.9 \mathrm{bc}$ & $6.7 \mathrm{abc}$ & $8.7 \mathrm{abc}$ & - \\
\hline $2: \leq 25 \%$ blackened skin & $0 \mathrm{a}$ & $1.7 \mathrm{bc}$ & $4.2 \mathrm{c}$ & $5.6 \mathrm{c}$ & $7.1 \mathrm{c}$ & - \\
\hline 3: $26-50 \%$ blackened skin & $0 \mathrm{a}$ & $1.5 \mathrm{c}$ & $4.7 \mathrm{bc}$ & $6.3 \mathrm{bc}$ & $8.1 \mathrm{bc}$ & - \\
\hline 4: $51-75 \%$ blackened skin & $0 \mathrm{a}$ & $2.1 \mathrm{ab}$ & $5.6 \mathrm{ab}$ & $7.6 \mathrm{ab}$ & $9.5 \mathrm{ab}$ & - \\
\hline 5: > 75\% blackened skin & $0 \mathrm{a}$ & $2.5 \mathrm{a}$ & $6.2 \mathrm{a}$ & $8.3 \mathrm{a}$ & $10.8 \mathrm{a}$ & - \\
\hline \multicolumn{7}{|c|}{ February (average weight loss 3.3\%) } \\
\hline 1: fully green & $0 \mathrm{a}$ & $1.2 \mathrm{~b}$ & $2.9 \mathrm{~b}$ & $4.0 \mathrm{~b}$ & $5.1 \mathrm{~b}$ & - \\
\hline $2: \leq 25 \%$ blackened skin & $0 \mathrm{a}$ & $1.2 \mathrm{~b}$ & $2.9 \mathrm{~b}$ & $4.0 \mathrm{~b}$ & $5.1 \mathrm{~b}$ & - \\
\hline 3: $26-50 \%$ blackened skin & $0 \mathrm{a}$ & $1.7 \mathrm{a}$ & $4.1 \mathrm{a}$ & $5.7 \mathrm{a}$ & $6.6 \mathrm{a}$ & - \\
\hline 4: $51-75 \%$ blackened skin & $0 \mathrm{a}$ & $1.4 \mathrm{~b}$ & $3.7 \mathrm{a}$ & $5.2 \mathrm{a}$ & $6.5 \mathrm{a}$ & - \\
\hline 5: > 75\% blackened skin & $0 \mathrm{a}$ & $1.4 \mathrm{~b}$ & $3.7 \mathrm{a}$ & $5.2 \mathrm{a}$ & $6.6 \mathrm{a}$ & - \\
\hline \multicolumn{7}{|c|}{ March (average weight loss $4.4 \%$ ) } \\
\hline 1: fully green & $0 \mathrm{a}$ & $2.0 \mathrm{ab}$ & $4.3 a b$ & $5.7 \mathrm{~b}$ & $7.1 \mathrm{~b}$ & - \\
\hline $2: \leq 25 \%$ blackened skin & $0 \mathrm{a}$ & $1.9 \mathrm{~b}$ & $4.0 \mathrm{~b}$ & $5.4 \mathrm{~b}$ & $6.9 \mathrm{~b}$ & - \\
\hline 3: $26-50 \%$ blackened skin & $0 \mathrm{a}$ & $2.2 a b$ & $4.7 a b$ & $6.4 \mathrm{a}$ & $8.1 \mathrm{ab}$ & - \\
\hline 4: $51-75 \%$ blackened skin & $0 \mathrm{a}$ & $2.5 \mathrm{a}$ & $5.4 \mathrm{a}$ & $6.8 \mathrm{a}$ & $9.4 \mathrm{a}$ & - \\
\hline 5: > 75\% blackened skin & $0 \mathrm{a}$ & $2.2 a b$ & $4.9 \mathrm{ab}$ & $6.7 \mathrm{a}$ & $8.6 \mathrm{ab}$ & - \\
\hline \multicolumn{7}{|c|}{ April (average weight loss 3.9\%) } \\
\hline 1: fully green & $0 \mathrm{a}$ & $1.7 \mathrm{~b}$ & $3.5 \mathrm{~b}$ & $4.8 \mathrm{~b}$ & $6.0 \mathrm{~b}$ & - \\
\hline $2: \leq 25 \%$ blackened skin & $0 \mathrm{a}$ & $1.7 \mathrm{~b}$ & $3.5 \mathrm{~b}$ & $4.8 \mathrm{~b}$ & $6.0 \mathrm{~b}$ & - \\
\hline 3: $26-50 \%$ blackened skin & $0 \mathrm{a}$ & $2.1 \mathrm{a}$ & $4.3 \mathrm{a}$ & $5.9 \mathrm{a}$ & $7.4 \mathrm{a}$ & - \\
\hline 4: $51-75 \%$ blackened skin & $0 \mathrm{a}$ & $2.3 \mathrm{a}$ & $4.6 \mathrm{a}$ & $6.2 \mathrm{a}$ & $7.7 \mathrm{a}$ & - \\
\hline 5: > 75\% blackened skin & $0 \mathrm{a}$ & $2.0 \mathrm{ab}$ & $4.1 \mathrm{ab}$ & $5.6 \mathrm{ab}$ & $7.0 \mathrm{ab}$ & - \\
\hline
\end{tabular}

analysis of variance showed significant differences $(P \leq 0.05)$ for main factors but not for the interaction. Dry matter content in fruit harvested in October was the lowest (20.5\% of fresh weight), whereas fruit harvested in March and April showed the highest content (35.7\% and 33.7\%, respectively). Similarly, dry matter content increased with the degree of blackened skin. Fruit classified into categories 3, 4 and 5 averaged 34.1\%, 34.1\% and $34.7 \%$ dry matter; whereas fruit dry matter in categories 1 and 2 was significantly lower (29.5\% and 32.9\%, respectively). These results were expected as it has been demonstrated that there is a measurable and significant relationship between dry matter and physiological maturity of avocado fruit, and that fruit quality does not necessarily decrease when harvested late [7-9].

\subsection{Weight loss}

Weight loss decreased significantly $(P<$ $0.05)$ with harvest date but increased concomitantly with ripening category (table II). 
Table III.

Effect of ripening degree on percent of blackened skin of Hass avocado fruit by harvest date, in relation with the sampling dates during storage. Harvest : beginning of the simulation of terrestrial shipment inside a cold storage room for $7 d ;(7+0) d$ : end of the refrigeration period; $(7+3) d,(7+5) d,(7+7) d,(7+10) d$ : samplings every $3 d$ during storage with market conditions.

\begin{tabular}{|c|c|c|c|c|c|c|}
\hline \multirow[t]{2}{*}{ Ripening degree } & \multicolumn{6}{|c|}{ Sampling date } \\
\hline & Harvest & $(7+0) d$ & $(7+3) d$ & $(7+5) d$ & $(7+7) d$ & $(7+10) d$ \\
\hline \multicolumn{7}{|l|}{ October } \\
\hline 1: fully green & 0 & 0 & 40 & 60 & 80 & 100 \\
\hline \multicolumn{7}{|l|}{ December } \\
\hline 1: fully green & $0 \mathrm{a}$ & $0 \mathrm{a}$ & $10 a$ & $30 \mathrm{~b}$ & $70 \mathrm{~b}$ & $100 \mathrm{a}$ \\
\hline $2: \leq 25 \%$ blackened skin & $0 \mathrm{a}$ & $10 a$ & $20 \mathrm{a}$ & $60 a$ & $90 \mathrm{a}$ & $100 \mathrm{a}$ \\
\hline \multicolumn{7}{|l|}{ January } \\
\hline 1: fully green & $0 \mathrm{c}$ & $0 \mathrm{c}$ & $0 \mathrm{c}$ & $100 \mathrm{a}$ & $100 \mathrm{a}$ & - \\
\hline $2: \leq 25 \%$ blackened skin & $0 \mathrm{c}$ & $0 \mathrm{c}$ & $10 \mathrm{c}$ & $100 \mathrm{a}$ & $100 \mathrm{a}$ & - \\
\hline 3: $26-50 \%$ blackened skin & $10 \mathrm{~b}$ & $30 \mathrm{~b}$ & $50 \mathrm{~b}$ & $100 \mathrm{a}$ & $100 \mathrm{a}$ & - \\
\hline 4: $51-75 \%$ blackened skin & $90 \mathrm{a}$ & $100 \mathrm{a}$ & $100 \mathrm{a}$ & $100 \mathrm{a}$ & $100 \mathrm{a}$ & - \\
\hline 5: > 75\% blackened skin & $100 \mathrm{a}$ & $100 \mathrm{a}$ & $100 \mathrm{a}$ & $100 \mathrm{a}$ & $100 \mathrm{a}$ & - \\
\hline \multicolumn{7}{|l|}{ February } \\
\hline 1: fully green & $0 \mathrm{c}$ & $0 \mathrm{c}$ & $0 \mathrm{c}$ & $100 \mathrm{a}$ & $100 \mathrm{a}$ & - \\
\hline $2: \leq 25 \%$ blackened skin & $0 \mathrm{c}$ & $0 \mathrm{~b}$ & $30 \mathrm{~b}$ & $100 \mathrm{a}$ & $100 \mathrm{a}$ & - \\
\hline 3: $26-50 \%$ blackened skin & $60 \mathrm{~b}$ & $80 \mathrm{~b}$ & $90 \mathrm{a}$ & $100 \mathrm{a}$ & $100 \mathrm{a}$ & - \\
\hline 4: $51-75 \%$ blackened skin & $90 \mathrm{a}$ & $100 \mathrm{a}$ & $100 \mathrm{a}$ & $100 \mathrm{a}$ & $100 \mathrm{a}$ & - \\
\hline 5: > 75\% blackened skin & $100 \mathrm{a}$ & $100 \mathrm{a}$ & $100 \mathrm{a}$ & $100 \mathrm{a}$ & $100 \mathrm{a}$ & - \\
\hline \multicolumn{7}{|l|}{ March } \\
\hline 1: fully green & $0 \mathrm{c}$ & $0 \mathrm{c}$ & $0 d$ & $100 \mathrm{a}$ & $100 \mathrm{a}$ & - \\
\hline $2: \leq 25 \%$ blackened skin & $0 \mathrm{c}$ & $0 \mathrm{c}$ & $20 \mathrm{c}$ & $100 \mathrm{a}$ & $100 \mathrm{a}$ & - \\
\hline 3: $26-50 \%$ blackened skin & $30 \mathrm{~b}$ & $30 \mathrm{~b}$ & $40 \mathrm{~b}$ & $100 \mathrm{a}$ & $100 \mathrm{a}$ & - \\
\hline 4: $51-75 \%$ blackened skin & $90 \mathrm{a}$ & $90 \mathrm{a}$ & $100 \mathrm{a}$ & $100 \mathrm{a}$ & $100 \mathrm{a}$ & - \\
\hline 5: > 75\% blackened skin & $100 \mathrm{a}$ & $100 \mathrm{a}$ & $100 \mathrm{a}$ & $100 \mathrm{a}$ & $100 \mathrm{a}$ & - \\
\hline \multicolumn{7}{|l|}{ April } \\
\hline 1: fully green & $\mathrm{Oc}$ & $\mathrm{Oc}$ & $20 d$ & $100 \mathrm{a}$ & $100 \mathrm{a}$ & - \\
\hline $2: \leq 25 \%$ blackened skin & $0 \mathrm{c}$ & $\mathrm{Oc}$ & $40 \mathrm{c}$ & $100 \mathrm{a}$ & $100 \mathrm{a}$ & - \\
\hline 3: $26-50 \%$ blackened skin & $20 \mathrm{~b}$ & $60 \mathrm{~b}$ & $80 \mathrm{~b}$ & $100 \mathrm{a}$ & $100 \mathrm{a}$ & - \\
\hline 4: $51-75 \%$ blackened skin & $100 \mathrm{a}$ & $100 \mathrm{a}$ & $100 \mathrm{a}$ & $100 \mathrm{a}$ & $100 \mathrm{a}$ & - \\
\hline 5: > 75\% blackened skin & $100 \mathrm{a}$ & $100 \mathrm{a}$ & $100 \mathrm{a}$ & $100 \mathrm{a}$ & $100 \mathrm{a}$ & - \\
\hline
\end{tabular}

In October, average weight loss was $7.1 \%$ and then declined until reaching $3.9 \%$ in April. This response could be the result of fruit having low dry matter content (20.5\%) early in the season. Regardless of harvest date, in general, weight loss was significantly higher in ripening categories 3, 4 and 5 than in categories 1 or 2 . The higher weight loss in fruit with more blackened skin could be attributed to those fruit having higher metabolic activity than less mature fruit. Erickson et al. [15] stated that mature fruit showed a peak respiratory rate $80 \mathrm{~h}$ after harvest, while green fruit reached the peak $5 \mathrm{~d}$ after being harvested.

\subsection{Blackened fruits and pulp firmness}

The degree of blackened skin and pulp firmness are the most important indicators to determine that a Hass avocado fruit is ready for consumption. The fruit becomes 
Table IV.

Effect of ripening degree on the pulp firmness of Hass avocado fruit by harvest date, in relation with the sampling dates during storage. Harvest : beginning of the simulation of terrestrial shipment inside a cold storage room for $7 \mathrm{~d} ;(7+0) \mathrm{d}$ : end of the refrigeration period; $(7+3) d,(7+5) d,(7+7) d,(7+10) d$ : samplings every $3 \mathrm{~d}$ during storage with market conditions.

\begin{tabular}{|c|c|c|c|c|c|c|}
\hline \multirow[t]{2}{*}{ Ripening degree } & \multicolumn{6}{|c|}{ Sampling date } \\
\hline & Harvest & $(7+0) d$ & $(7+3) d$ & $(7+5) d$ & $(7+7) d$ & $(7+10) d$ \\
\hline \multicolumn{7}{|l|}{ October } \\
\hline 1: fully green & 326 & 326 & 115 & 63 & 10 & 5 \\
\hline \multicolumn{7}{|l|}{ December } \\
\hline 1: fully green & 326 a & $326 \mathrm{a}$ & $192 \mathrm{a}$ & $76 a$ & $6 a$ & $5 a$ \\
\hline $2: \leq 25 \%$ blackened skin & 326 a & $326 \mathrm{a}$ & $193 a$ & $52 a$ & $7 a$ & $4 \mathrm{a}$ \\
\hline \multicolumn{7}{|l|}{ January } \\
\hline 1: fully green & 326 a & 326 a & $12 \mathrm{a}$ & $7 \mathrm{a}$ & $6 \mathrm{a}$ & - \\
\hline $2: \leq 25 \%$ blackened skin & 326 a & $326 a$ & $16 a$ & $8 a$ & $6 a$ & - \\
\hline 3: $26-50 \%$ blackened skin & 326 a & 326 a & $12 \mathrm{a}$ & $7 \mathrm{a}$ & $6 \mathrm{a}$ & - \\
\hline 4: $51-75 \%$ blackened skin & 324 a & 323 a & $14 \mathrm{a}$ & 7 a & $7 \mathrm{a}$ & - \\
\hline 5: $>75 \%$ blackened skin & $298 \mathrm{~b}$ & $300 \mathrm{~b}$ & $12 \mathrm{a}$ & $8 \mathrm{a}$ & $7 \mathrm{a}$ & - \\
\hline \multicolumn{7}{|l|}{ February } \\
\hline 1: fully green & 326 a & $326 \mathrm{a}$ & $84 \mathrm{a}$ & $22 \mathrm{a}$ & $7 \mathrm{a}$ & - \\
\hline $2: \leq 25 \%$ blackened skin & 326 a & 326 a & $117 \mathrm{a}$ & $10 a$ & $7 \mathrm{a}$ & - \\
\hline 3: $26-50 \%$ blackened skin & 326 a & $282 \mathrm{a}$ & $101 \mathrm{a}$ & $10 \mathrm{a}$ & $6 \mathrm{a}$ & - \\
\hline 4: $51-75 \%$ blackened skin & 326 a & $326 \mathrm{a}$ & $64 \mathrm{a}$ & $49 a$ & $7 \mathrm{a}$ & - \\
\hline 5: > 75\% blackened skin & 324 a & $264 \mathrm{a}$ & $158 \mathrm{a}$ & 8 a & $8 \mathrm{a}$ & - \\
\hline \multicolumn{7}{|l|}{ March } \\
\hline 1: fully green & 326 a & $326 \mathrm{a}$ & $275 a$ & $100 \mathrm{a}$ & $8 \mathrm{a}$ & - \\
\hline $2: \leq 25 \%$ blackened skin & 326 a & $326 \mathrm{a}$ & $284 \mathrm{a}$ & 68 a & $9 \mathrm{a}$ & - \\
\hline 3: $26-50 \%$ blackened skin & 326 a & $326 \mathrm{a}$ & $173 a$ & $80 \mathrm{a}$ & $19 a$ & - \\
\hline 4: $51-75 \%$ blackened skin & 326 a & 326 a & $203 a$ & $114 \mathrm{a}$ & $9 a$ & - \\
\hline 5: > 75\% blackened skin & $322 \mathrm{~b}$ & 325 a & $280 \mathrm{a}$ & $54 \mathrm{a}$ & $7 \mathrm{a}$ & - \\
\hline \multicolumn{7}{|l|}{ April } \\
\hline 1: fully green & 326 a & 326 a & $251 \mathrm{a}$ & $63 a b$ & $6 \mathrm{a}$ & - \\
\hline $2: \leq 25 \%$ blackened skin & 326 a & 326 a & $233 \mathrm{a}$ & $122 \mathrm{a}$ & $6 \mathrm{a}$ & - \\
\hline 3: $26-50 \%$ blackened skin & 326 a & 326 a & $201 \mathrm{a}$ & $8 b$ & $5 \mathrm{a}$ & - \\
\hline 4: $51-75 \%$ blackened skin & 326 a & $326 \mathrm{a}$ & $127 \mathrm{~b}$ & $10 \mathrm{~b}$ & $7 \mathrm{a}$ & - \\
\hline 5: > 75\% blackened skin & 326 a & $319 \mathrm{~b}$ & $85 b$ & $23 \mathrm{~b}$ & $6 \mathrm{a}$ & - \\
\hline
\end{tabular}

completely black due to an initial decrease in chlorophyll content followed by an increase in anthocyanin content [4] and loss of firmness as a result of a marked climacteric rise in respiration after harvest [16]. Our results showed that, in general, the percentage of blackened skin and loss of firmness of Hass avocado fruit was not affected by the ripening category of harvested fruit (tables III, IV). These results demonstrate that the degree of blackened skin was not associated with a corresponding decrease in pulp firmness, as reported previously [3]. Therefore, there is no reason for retailers to reject or downgrade fruit with blackened skin, since fruit quality and shelf life were not affected by this factor.

\subsection{Pulp color}

Harvest date and degree of blackened skin significantly affected $(P<0.05)$ pulp color (figure 2). Regarding the effect of harvest date, two color groups were differentiated: 

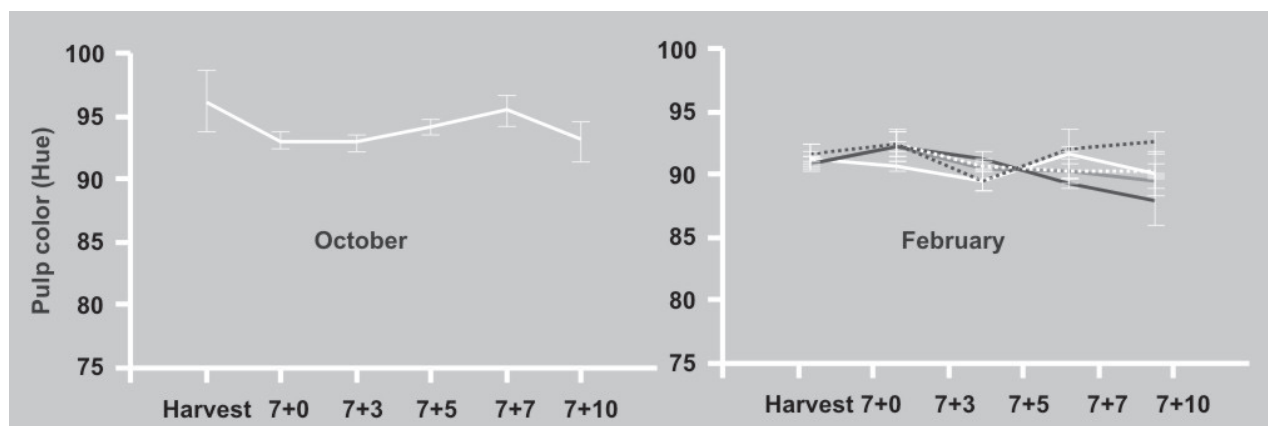

Figure 2.

Effect of harvest date and ripening degree on pulp color of Hass avocado fruit. Each point is the mean of six observations \pm the standard error. For sampling dates: harvest is the beginning of the simulation of terrestrial shipment inside a cold storage room for $7 \mathrm{~d}$; $(7+0) \mathrm{d}$ is the end of the refrigeration period; $(7+3) d,(7+5) d,(7+7) d$,
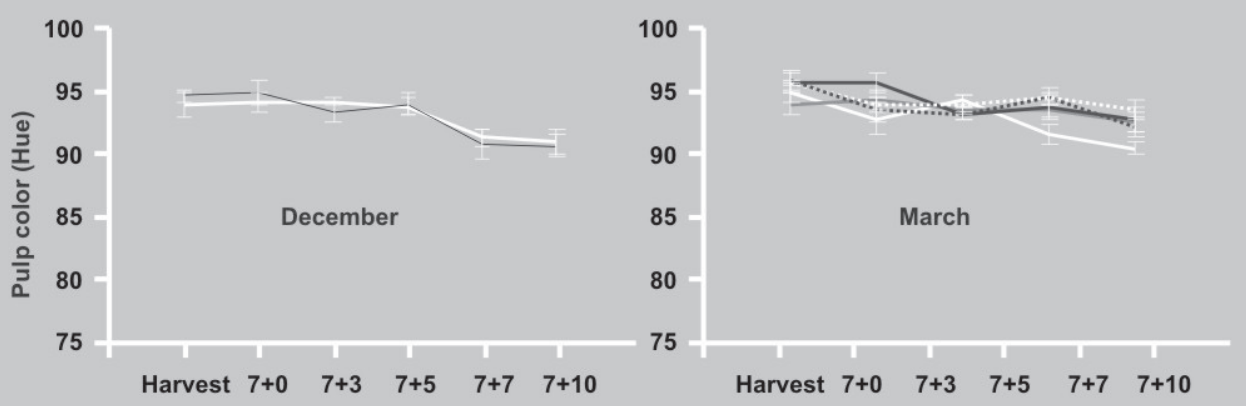

$(7+10) d$ are samplings every 3 d during storage with market conditions.
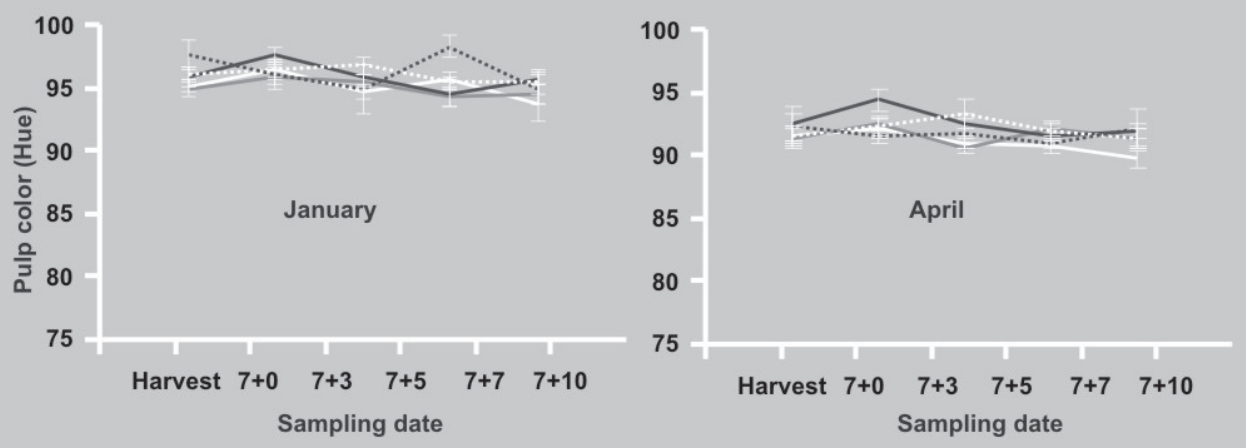

- Fully green - $\leq \mathbf{2 5 \%}$ blackened skin - $26-50 \%$ blackened skin

51-75\% blackened skin _....... > 75\% blackened skin

in the first one, there are fruit harvested in January, October, March and December, which had average pulp color of 94.6, 94.1, 93.7 and 93.0, respectively; in the other group, there are fruit harvested in February and April, which had an average color of 91.2 and 91.1, respectively. Higher values indicate greener pulp color, while lower values denote slight yellowness of pulp. Similarly to harvest date, ripening degree resulted in the differentiation of two groups for the pulp color: one formed by fruit from categories 3, 4 and 5, with average values of 93.2, 93.3 and 93.4, respectively, and a second one formed by categories 1 and 2 with average values of 92.3 and 92.0, respectively.

\section{Conclusions}

- Pulp dry matter content increased with harvest date and degree of blackened skin. 
- Weight loss decreased significantly with harvest date but increased with degree of blackened skin. Ripening degree categories 3,4 and 5 (fruit with $>25 \%$ of blackened skin) had higher weight losses than categories 1 or 2 (fruit with $\leq 25 \%$ of blackened skin).

- Harvest date had a significant effect on pulp firmness but the degree of blackened skin was not associated with a decrease in pulp firmness.

- The data showed that there is no reason to reject or downgrade fruit with blackened skin, since fruit quality and shelf life were not affected by harvest time and ripening degree.

\section{References}

[1] Salazar-García S., Zamora-Cuevas L., VegaLópez R.J., Update on the avocado industry of Michoacán, México, Calif. Avocado Soc. Yearb. 87 (2005) 31-44.

[2] LeeS.K., Young R.E, Schiffman P.M., Coggins C.W., Maturity studies of avocado fruit based on picking dates and dry weight, J. Am. Soc. Hortic. Sci. 108 (3) (1983) 390-394.

[3] Osuna-García J.A., Doyon G., Salazar-García S., González-Durán I.J.L., Goenaga R., Relationship between skin color and some quality characteristics of exportable Hass avocado fruit, in: Proc. 53rd Annu. Meet. Interam. Soc. Trop. Hortic., ISTH, Morelia, México, 2007, p. 93.

[4] Cox K.A., McGhie T.K., White A., Woolf A.B., Skin colour and pigment changes during ripening of Hass avocado fruit, Postharv. Biol. Technol. 31 (2004) 287-294.
[5] Werman M.J., Neeman I., Avocado oil production and chemical characteristics, J. Am. Oil Chem. Soc. 64 (2) (1987) 229-232.

[6] Erickson L.C., Eaks J.L., Porter G.G., Overmaturity in Hass avocados, Calif. Avocado Soc. Yearb. 54 (1970) 62-65.

[7] Hofman P.J., Jobin-Décor M., Giles J., Percentage of dry matter and oil content are not reliable indicators of fruit maturity or quality in late-harvested Hass avocado, HortScience 35 (4) (2000) 694-695.

[8] Ozdemir F., Topuz A., Changes in dry matter, oil content and fatty acids composition of avocado during harvesting time and postharvesting ripening period, Food Chem. 86 (2004) 79-83.

[9] Ranney C., Relationship between physiological maturity and percent dry matter of avocados, Calif. Avocado Soc. Yearb. 75 (1991) 71-85.

[10] Salazar-García S., Floración y fructificación, In: Téliz D., Mora A. (Coord.), El aguacate y su manejo integrado, segundo ed., Ed. Mundi-Prensa, México, 2007, pp. 64-86.

[11] Schroeder C.A., Physiological gradient in avocado fruit, Calif. Avocado Soc. Yearb. 69 (1985) 137-144.

[12] Lee S.K., Coggins C.W., Dry weight method for determination of avocado fruit maturity, Calif. Avocado Soc. Yearb. 66 (1982) 67-70.

[13] Dowdy S., Wearden S., Statistics for Research, John Wiley \& Sons, N.Y., U.S.A., 1991.

[14] Anon., SAS user's guide: Statistics, Version 6.12., SAS Inst., Cary, N.C., U.S.A.,1998.

[15] Erickson L.C., Eaks I.L., Porter G.G., Overmaturity in Hass avocados, Calif. Avocado Soc. Yearb. 54 (1970-71) 62-65.

[16] Schroeder C.A., Growth and development of the avocado fruit, Calif. Avocado Soc. Yearb. 42 (1958) 114-118. 


\section{Efecto de la época de cosecha y el grado de madurez sobre la calidad y vida de anaquel del aguacate Hass en México.}

Resumen - Introducción. Canadá es un importante importador de aguacate de México. Para la mayoría de la época de cosecha, los frutos alcanzan un adecuado contenido de materia seca, lo que determina que los frutos maduren adecuadamente y en consecuencia, la calidad y vida de anaquel son excelentes. Sin embargo, en frutos cosechados después de enero se observa un incremento del contenido de materia seca, lo que induce a un ennegrecimiento parcial o total de la cáscara. Envíos de fruta a Canadá conteniendo frutos con ennegrecimiento de la cáscara son rechazados porque esta característica erróneamente se asocia con baja firmeza de pulpa y corta vida de anaquel. El objetivo de nuestra investigación fue determinar el efecto de la época de cosecha y el grado de madurez sobre la calidad inicial y la vida de anaquel de frutos de aguacate Hass. Material y métodos. Los frutos fueron cosechados desde Octubre del 2007 hasta Abril del 2008 y se agruparon en cinco categorías de madurez acorde al grado de ennegrecimiento de la cáscara. Inmediatamente de la cosecha, los frutos se almacenaron en cámara refrigerada durante siete días para simular el traslado terrestre a Canadá. Al término de la simulación del traslado, los frutos fueron almacenados bajo condiciones de simulación de mercadeo hasta que alcanzaron madurez de consumo. El contenido de materia seca se determinó solo al inicio del periodo del almacenamiento, en tanto que la cuantificación de la pérdida de peso, el vire de color de cáscara, la firmeza y el color de pulpa se realizó al inicio del almacenamiento, al término de la refrigeración y cada tres días durante las condiciones de mercadeo. Resultados y discusión. El contenido de materia seca, el color de cáscara y el ángulo de tono de la pulpa se incrementaron significativamente con la época de cosecha y el grado de madurez. La pérdida de peso disminuyó con la época de cosecha pero se incrementó conforme al grado de madurez, en tanto que la firmeza fue afectada por la época de cosecha pero no estuvo asociada con el grado de madurez. Conclusión. No hay razón para rechazar o degradar fruta con ennegrecimiento de la cáscara ya que la calidad y vida de anaquel no fueron afectadas.

México / Persea americana / frutas / maduramiento / contenido de materia seca / pérdida de peso / color / piel (vegetal) / firmeza 